\title{
PERBANDINGAN KOMBINASI ABDOMINAL STRETCHING DAN CORE STRENGTHENING EXERCISE DENGAN KOMBINASI ABDOMINAL STRETCHING DAN PILATES EXERCISE DALAM MENURUNKAN INTENSITAS DISMENORE PRIMER
}

\section{A Md Dwi Purwitasari ${ }^{1}$. Luh Putu Ratna Sundari ${ }^{2}$. Indra Lesmana ${ }^{3}$. I Wayan Weta ${ }^{4}$. I Desak Made Wihandani ${ }^{5}$. Ni Made Swasti Wulanyani ${ }^{6}$}

${ }^{1}$ Program Magister Fisiologi Keolahragaan, Fakultas Kedokteran, Universitas Udayana, Denpasar ${ }^{2}$ Departemen Ilmu Faal, Fakultas Kedokteran, Universitas Udayana, Denpasar ${ }^{4}$ Departemen Biomedik, Fakultas Kedokteran, Universitas Udayana, Denpasar ${ }^{5}$ Departemen Biokimia, Fakultas Kedokteran, Universitas Udayana, Denpasar ${ }^{6}$ Departemen Psikologi, Fakultas Kedokteran, Universitas Udayana, Denpasar

${ }^{3}$ Fakultas Fisioterapi, Universitas Esa Unggul, Jakarta e-mail : dayupurwita13@gmail.com

\begin{abstract}
ABSTRAK
Setiap remaja putri akan melewati masa pubertas yang ditandai dengan terjadinya menstruasi. Pada saat fase menstruasi biasanya disertai rasa nyeri, keluhan ini disebut dengan dismenore. Nyeri yang dirasakan dapat menggangu aktivitas sehari-hari. Ada beberapa metode yang dapat diberikan untuk menurunkan nyeri yang dirasakan saat haid. Diantaranya adalah metode abdominal stretching, core strengthening, dan pilates exercise yang bertujuan untuk menurunkan nyeri dan meningkatkan kekuatan otot disekitar perut hingga panggul. Penelitian ini bertujuan untuk mengetahui mana yang lebih efektif antara metode abdominal stretching dan core strengthening excercise dibandingkan metode abdominal stretching dan pilates exercises dalam menurunkan intensitas dismenore primer. Penelitian ini menggunakan rancangan eksperimental dengan pre test and post test contol group design. Lokasi penelitian dilakukan di SMA Dwijendra Denpasar,Bali dengan jumlah sampel 28 orang yang memiliki kategori dismenore primer dengan derajat nyeri sedang hingga berat, dibagi menjadi 2 kelompok perlakuan. Kelompok I diberikan abdominal stretching dan core strengthening exercise, kelompok II diberikan abdominal stretching dan pilates exercises. Alat ukur yang digunakan dalam penelitian ini adalah Visual Analouge Scale (VAS). Sebaran data dalam penelitian ini menggunakan analisi Wilcoxon dan Man Whitney karena data tidak berdistribusi normal. Hasil dalam penelitian ini yaitu metode abdominal stretching dengan core strengthening exercise dapat menurunkan intensitas dismenore primer dengan nilai signifikan $\mathrm{p}=0,001$ dengan nilai median VAS 6 menjadi 4 metode abdominal stretching dengan pilates excercise dapat menurunkan intensitas dismenore primer dengan nilai signifikan $\mathrm{p}=0,001$ dengan nilai median VAS 6 menjadi 4 . Antara kelompok I dan kelompok II, tidak didapat perbedaan pre test $(\mathrm{P}=0,178)$, post tes $(\mathrm{P}=0,173)$, dan perubahan $(\mathrm{P}=0,561)$ Kesimpulan dari penelitian ini adalah tidak ada perbedaan efektivitas antara metode abdominal stretching dengan core strengthening dan abdominal stretching dengan pilates exercises dalam menurunkan intensitas dismenore primer.
\end{abstract}

Kata Kunci : Dismenore, abdominal stretching, core strengthening, pilates exercises 


\title{
COMPARISON OF COMBINATION ABDOMINAL STRETCHING AND CORE STRENGTHENING EXERCISE WITH COMBINATION ABDOMINAL STRETCHING AND PILATES EXERCISE IN DECREASING THE PRIMER DISMENORE INTENSITY
}

\begin{abstract}
Every adolescent woman will go through puberty marked by menstruation. At the time of the menstrual phase is usually accompanied by pain, this complaint is called dysmenorrhea. Pain that is felt can interfere with daily activities. There are several methods that can be given to reduce pain that is felt during menstruation. Among them are abdominal stretching, core strengthening, and pilates exercise methods that aim to reduce pain and increase muscle strength around the abdomen to the pelvis. This study aims to determine which is more effective between the abdominal stretching and core strengthening excercise methods than the abdominal stretching and pilates exercises method in reducing the intensity of primary dysmenorrhea.This study uses an experimental design with pre-test and post-test control group design. The study was conducted at Dwijendra High School Denpasar, Bali with a sample of 28 people who had a primary dysmenorrhea category with moderate to severe pain degrees, divided into 2 treatment groups. Group I was given abdominal stretching and core strengthening exercise, group II was given abdominal stretching and pilates exercises. The measuring instrument used in this study was the Visual Analytical Scale (VAS). Distribution in this study used Wilcoxon and man whitney analysis because the data are not normally distributed.The results in this study used the abdominal stretching and core strengthening exercise reduce the intensity of primary dysmenorrhea with a significant value of $p=0.001$ with a median VAS value of 6.29 to 4.79 , the abdominal stretching and pilates excercise reduce the intensity of primary dysmenorrhea with a significant value of $\mathrm{p}=0.001$ with a median VAS value of 5.93 to 4.29. There was not difference between group I and group II, test $(\mathrm{P}=0,178)$, post tes $(\mathrm{P}=0,173)$, dan perubahan $(\mathrm{P}=0,561)$ The conclusion of this study is that there is equal in effectiveness between the methods of abdominal stretching and core strengthening with abdominal stretching and pilates exercises in reducing the intensity of primary dysmenorrhea
\end{abstract}

Keywords: Dysmenorrhea, abdominal stretching, core strengthening, pilates exercises

\section{PENDAHULUAN}

Perubahan- perubahan yang terjadi pada manusia tentu akan mempengaruhi fisik dan mental seseorang. Perubahan yang terjadi pada masa anak -anak menuju dewasa disebut dengan pubertas, umumnya masa ini dialami usia 14 tahun pada pria dan usia 12 tahun pada wanita. Salah satu tanda pubertas pada wanita adalah terjadinya menstruasi(Proverawati,2009). Menstruasi merupa- kan proses pelepasan dinding rahim yang disertai dengan pendarahan yang terjadi secara berulang setiap bulan, kecuali pada saat terjadi kehamilan. Hari pertama terjadinya menstruasi dihitung sebagai awal setiap siklus menstruasi. Menstruasi akan terjadi 3- 7 hari (Anurogo,2011. Setiap wanita memiliki pengalaman menstruasi yang berbeda-beda. Sebagian wanita mendapatkan menstruasi tanpa keluhan, namun tidak sedikit dari mereka yang mendapatkan menstruasi disertai keluhan berupa dismenore yang mengakibatkan rasa ketidaknyamanan yaitu nyeri ringan hingga berat pada perut bagian bawah, daerah pinggang dan sisi medial paha, serta berdampak terhadap gangguan aktivitas 
seperti : tidak konsentrasi dalam menerima pelajaran, menurunnya prestasi belajar serta sering tidak masuk sekolah (Badziad,30030.

Dismenore merupakan rasa nyeri yang dirasakan pada fase haid hal ini disebabkan oleh karena kadar hormon ovarium yaitu progesteron dan estrogen menurun. Penurunan hormon ini yang menyebabkan pembebasan suatu prostaglandin uterus. Salah satu fungsi dari prostaglandin adalah berfungsi untuk merangsang kontraksi ringan myometrium (Fortier,2008\& Sundari,2017). Kontraksi uterus yang terlalu kuat akibat produksi prostaglandin berlebihan menyebabkan nyeri (Winkjosastro,2009). Dismenore yang terjadi pada wanita tergolong atas dua jenis dismenore yaitu dismenore primer dan dismenore sekunder. Dismenore primer merupakan nyeri haid karena aktivitas uterus, tanpa adanya kondisi patologis dari pelvis. Hasil sensus penduduk tahun 2010 menunjukkan bahwa jumlah penduduk Indonesia yaitu sebesar 237.641.326 jiwa, dan 63,4 juta atau 27\% diantaranya adalah remaja usia 10-24 tahun. Di Indonesia angka kejadian dismenore tipe primer adalah sekitar 54,89\% sedangkan penderita dengan dismenore sekunder adalah $45,11 \%$ (Nurwna,2017).

Banyak cara untuk menghilangkan atau menurunkan dismenore, baik secara farmakologis dan non farmakologis dengan metode latihan fisik dan gabungan yaitu gabungan antara obat dengan latihan fisik. Fisioterapi yang merupakan salah satu tenaga medis, dengan modalitas terapi latihan diharapkan mampu memberikan exercise yang mampu menurunkan nyeri pada wanita yang mengalami dismenore primer. Latihan tubuh merupakan manajemen nonfarmakologis yang lebih aman karena menggunakan proses fisiologis, dengan cara menerapkan latihan-latihan gerak tubuh baik secara aktif maupun pasif (Kisner,2012). Latihan fisik yang umumnya dapat diberikan untuk menangani keluhan yang disebabkan dismenore primer seperti abdominal stretching, core strengthening dan pilates exercise. abdominal stretching yang dapat memberikan efek fisiologis yang sistematis dan terencana (Brown,2010).

Abdominal stretching adalah suatu latihan yang bertujuan untuk meningkatkan elastisitas dan kekuatan otot - otot tulang belakang, panggul, diafragma. Selain itu meningkatkan jumlah oksigen dan nutrisi yang diedarkan ke rahim, sehingga akan dapat menurunkan nyeri dan sakit pada punggung, merangsang nafsu makan, menurunkan anemia, menjaga keseimbangan hormone (Bustan,2018).

Core strengthening merupakan salah satu latihan yang dapat dilakukan dalam penguatan otot abdominal terutama pada kelompok core muscle. Core strengthening juga dideskripsikan sebagai kontrol otot yang ada di sekitar tulang belakang lumbalis yang bertujuan untuk menjaga stabilitas fungsional (Bill,2010).

Pilates exercise merupakan salah satu teknik relaksasi yang dapat digunakan untuk menurunkan rasa nyeri, hal ini disebabkan oleh karena pada saat melakukan latihan maka pada otak dan susunan saraf tulang belakang akan menghasilkan hormone endorphin, hormone ini berfungsi sebagai obat penenang alami dan menimbulkan rasa nyaman (Sari,2017).

\section{METODE PENELITIAN}

Penelitian ini dilakukan di SMA Dwijendra Denpasar. Penelitian ini dilakukan pada bulan Januari hingga Maret 2020. Penelitian bersifat eksperimental dengan rancangan pre-test and post test control group design. Alat ukur yang digunakan adalah Visual Analogue Scale (VAS) merupakan alat pengukuran intensitas nyeri yang dianggap paling efisien 
dalam pengaturan klinis. VAS umumnya disajikan dalam bentuk garis horizontal ${ }^{13}$.

\section{A. Sampel dan Populasi}

Teknik pengambilan sampel dilakukan dengan teknik probability sampling (simple random sampling) dengan menggunakan kriteria yang telah ditetapkan peneliti.. Populasi penelitian ini adalah seluruh siswi SMA Dwijendra Denpasar yang mengalami dismenore. Sampel yang digunakan berjumlah 28 orang yang kemudian dibagi menjadi 2 kelompok perlakuan. Pada kelompok I diberikan kombinasi abdominal stretching dan core strengthening kemudian kelompok II diberikan kombinasi abdominal stretching dan pilates exercise.

\section{B. Pengumpulan Data Penelitian}

Langkah pertama diawali dengan persiapan penelitian meliputi pengajuan ijin penelitian, ijin peminjaman ruangan dan fasilitas yang mendukung terlaksananya penelitian kepada pihak Sekolah SMA Dwijendra Denpasar. Langkah kedua mencari siswa yang memenuhi kriteria insklusi dengan cara memberikan form kuesioner yang berisi, identitas diri dan kategori nyeri haid yang dirasakan , kemudian subyek penelitian diarahkan datang ke lapangan untuk diberikan penjelasan dan perencanaan jadwal tentang rencana penelitian, manfaat penelitian dan program penelitian. Penjelasan tersebut diberikan kepada semua subyek yang menjadi subyek agar mengerti dan memahami maksud dan tujuan penelitian. Subyek yang bersedia ikut dalam penelitian diminta mengisi dan menandatangani surat persetujuan (Informed Consent). Kemudian kelompok I diberikan penerapan kombinasi abdominal stretching dan core strengthening pada kelompok II diberikan penerapan kombinasi abdominal stretching dan pilates exercise selama 12 minggu perlakuan, setiap hari Selasa, Kamis dan Sabtu oleh peneliti yang didampingi oleh tenaga fisioterapis yang berkompeten.
Abdominal stretching ini terdiri dari gerakan : cat stretch selama $2 \times 10$ hitungan, lower trunk rotation selama $2 \times 10$ hitungan, buttock/hip stretch selama $2 \times 10$ hitungan, abdominal strengthening selama $2 \times 10$ hitungan, lower abdominal strengthe -ning selama $15 \mathrm{x}$ hitungan dan the bridge position selama $2 \times 10$ hitungan dan dilakukan sebanyak $3 x$ set. Jadi total 1 set akan dilakukan selama 115 hitungan dan kemudian dilanjutkan dengan istirahat selama 10 detik diantara setiap set.

Core strengthening exercise terdiri dari gerakan: bridging selama 10 hitungan, single leg bridging selama 10 hitungan, modified plank selama 20 hitungan, front plank selama 20 hitungan, side plank selama 20 hitungan. Masing-masing gerakan dilakukan sebanyak $3 x$ set. Jadi total 1 set akan dilakukan selama 80 hitungan. Setelah 1 set selesai dilakukan maka dilanjutkan dengan istirahat selama 15 detik.

Pilates exercises latihan ini terdiri dari 16 gerakan diantaranya: Lumbar stretch 3x, Spine stretch I 3x, Spine stretch II 4x, spine twist $3 \mathrm{x}$, child pose $5 \mathrm{x}$, the windmill $4 \mathrm{x}$, the saw $3 \mathrm{x}$, the mermaid $3 \mathrm{x}$, half curl $4 \mathrm{x}$, tiny step 3x, the hundred I 8x, rolling like a ball $5 \mathrm{x}$, rolling down $4 \mathrm{x}$, single leg circle $8 \mathrm{x}$, single leg stretch $8 \mathrm{x}$, double leg stretch $4 \mathrm{x}$. Masing-masing gerakan dilakukan sebanyak $2 \mathrm{x}$ set.

\section{Analisa Data}

\section{Uji Normalitas Data}

Uji normalitas dilakukan dengan Shapirowilk test untuk mengetahui sebaran data berdistribusi normal atau tidak. Hasil analisa data dengan pemaknaan data berdistribusi normal jika nilai $p>0,05$, dan data tidak berdistribusi normal jika nilai $\mathrm{p}<0,05$.

\section{Uji Homogenitas}

Uji homogenitas menggunakan Levene test. Pengujian ini dilakukan untuk mengetahui sebaran data bersifat homogen atau tidak. Pemaknaan data bersifat homogen jika nilai 
$\mathrm{p}>0,05$, dan data bersifat tidak homogen jika nilai $\mathrm{p}<0,05$.

\section{Uji Hipotesis}

Uji yang digunakan untuk hipotesis 1 dan 2 menggunakan uji wilcoxon test menganalisis efek kombinasi abdominal stretching dan core strengthening kemudian kelompok II diberikan kombinasi abdominal stretching dan pilates exercise. Uji hipotesis 3 menggunakan Mann Whitney test untuk mengetahui perbandingan kombinasi abdominal stretching dan core strengthening dengan kombinasi abdominal stretching dan pilates exercise dalam menurunkan intensitas dismenore primer untuk menguji kemaknaan selisih pada kedua kelompok.

\section{HASIL PENELITIAN}

\section{A. Deskripsi Subjek Penelitian}

Tabel 5.1 Data Karakteristik Subjek Penelitian

\begin{tabular}{cccc}
\hline $\begin{array}{c}\text { Karakteristik } \\
\text { Subjek } \\
(\mathrm{n}=14)\end{array}$ & $\begin{array}{c}\text { Kelompok } \\
\mathrm{I}\end{array}$ & $\begin{array}{c}\text { Kelompo } \\
\mathrm{k} \mathrm{II} \\
(\mathrm{n}=14)\end{array}$ & $\begin{array}{c}\text { Selisi } \\
\mathrm{h}\end{array}$ \\
\hline IMT) & $22,35 \pm$ & $22,89 \pm$ & 0,54 \\
Umur & 0,99 & 0,77 & \\
Menstruasi & $0,79 \pm$ & $6,93 \pm$ & 0,14 \\
Usia & $12,30 \pm$ & 0,267 & $12,21 \pm$ \\
Menarche & 0,480 & 0,425 & 0,09 \\
\hline
\end{tabular}

Menurut kategori IMT, didapatkan karakteristik data sampel pada kelompok I : $22,35 \pm 0,99$. Sedangkan pada kelompok II : $22,89 \pm 0,77$. Selisih rerata pada kedua kelompok dalam kategori IMT adalah 0,54. Dalam kategori umur menstruasi diketahui bahwa karakteristik sampel pada kelompok I dengan rerata $6,79 \pm 0,426$ dan kelompok II dengan rerata $6,93 \pm 0,267$. Selisih rerata pada kedua kelompok adalah 0,14. Berdasarkan usia menarche diketahui bahwa usia mengalami menarche adalah di usia 12 tahun hingga 13 tahun. Rerata usia pada kelompok I adalah 12,30 dan pada kelompok II adalah 12,21.

Tabel 5.2 Hasil Uji Normalitas dan Homogenitas Data Nilai VAS

\begin{tabular}{|c|c|c|c|}
\hline \multirow[b]{2}{*}{$\begin{array}{l}\text { Nilai } \\
\text { VAS }\end{array}$} & \multicolumn{2}{|c|}{ Saphiro Wilk-Test $\mathrm{p}^{1}$} & \multirow[b]{2}{*}{$\begin{array}{c}\text { Levene- } \\
\text { Test } \\
\mathrm{p}^{2}\end{array}$} \\
\hline & $\begin{array}{c}\text { Klp } \\
\text { perlakuan } \\
\text { I } \\
(\mathrm{n}=14)\end{array}$ & $\begin{array}{c}\text { Klp } \\
\text { Perlakuan } \\
\text { II } \\
(n=14)\end{array}$ & \\
\hline $\begin{array}{l}\text { Sebelum } \\
\text { Perlakuan }\end{array}$ & 0,002 & 0,009 & 0,172 \\
\hline $\begin{array}{l}\text { Sesudah } \\
\text { Perlakuan }\end{array}$ & 0,006 & 0,087 & \\
\hline
\end{tabular}

Data hasil uji normalitas pada kedua kelompok berdistribusi tidak normal $\mathrm{p}>$ 0,05. Data hasil uji homogenitas data sebelum perlakuan pada kedua kelompok bersifat homogeny $\mathrm{p}>0,05$.

Tabel 5.3 Uji Perbandingan pengaruh perlakuan I dan perlakuan II

\begin{tabular}{|c|c|c|c|c|}
\hline \multirow{2}{*}{$\begin{array}{l}\text { Nilai } \\
\text { VAS }\end{array}$} & Pre-test & Post-test & Selisih & \multirow{2}{*}{$\begin{array}{c}\text { Nilai } \\
p^{*}\end{array}$} \\
\hline & $\begin{array}{c}\text { Median } \\
(\mathrm{P} 25- \\
\text { P75) }\end{array}$ & $\begin{array}{c}\text { Median } \\
\text { (P25- } \\
\text { P75) }\end{array}$ & $\begin{array}{c}\text { Median } \\
(\text { P25- } \\
\text { P75) }\end{array}$ & \\
\hline $\begin{array}{c}\text { Kelomp } \\
\text { ok I } \\
(n=14)\end{array}$ & $6(6-7)$ & $5(4-5)$ & $1,5(1-2)$ & 0,001 \\
\hline $\begin{array}{c}\text { Kelomp } \\
\text { ok II } \\
(n=14)\end{array}$ & $\begin{array}{l}6(5- \\
6,25)\end{array}$ & $4(4-5)$ & $1,5(1-2)$ & 0,001 \\
\hline $\begin{array}{l}\text { Nilai } \\
\mathrm{p}^{* *}\end{array}$ & 0,178 & 0,173 & 0,561 & \\
\hline
\end{tabular}

Keterangan :

$\mathrm{p}^{*}=$ nilai signifikansi Wilcoxon Test

$\mathrm{p}^{* *}=$ nilai signifikansi Mann-Whitney

Tabel 5.3. menunjukkan bahwa nilai uji hipotesis kelompok perlakuan I dan II 
didapatkan nilai signifikan $\mathrm{p}<0,05$ yang menyatakan hipotesis 1 dan 2 diterima. Selain itu didapatkan nilai dismenore primer sesudah perlakuan antara kelompok I dan kelompok II didapatkan nilai $\mathrm{p}$ sebesar 0,173 atau nilai $p>0,05$. Berdasarkan hasil uji selisih pada kelompok perlakuan I dan kelompok perlakuan II juga menunjukkan nilai $\mathrm{p}>0,001$ yang artinya nilai tersebut tidak signifikan. Hal ini menyatakan hipotesis 3 ditolak.

\section{PEMBAHASAN}

A. Perbandingan kombinasi abdominal stretching dan core strengthening exercise dengan perbandingan kombinasi abdominal stretching dan pilates exercise dalam menurunkan intensitas dismenore primer

Berdasarkan analisis data nilai VAS sebelum dan setelah perlakuan pada kelompok perlakuan I dan kelompok perlakuan II terjadi penurunan nilai VAS. Dari hasil tersebut dapat disimpulkan kombinasi abdominal stretching dan core strengthening exercise dengan kombinasi abdominal stretching dan pilates exercise dapat menurunkan intensitas dismenore primer.

Penelitian yang dilakukan oleh Gamit,2014 mengenai efek dari stretching exercise pada dismenore primer pada wanita dengan rentang usia 18-25 tahun yang didiagnosa mengalami dismenore primer, dengan jumlah sampel 30 orang. Kemudian dibagi menjadi 2 kelompok, pada kelompok 1 diberikan stretching exercise pada area abdomen sedangkan pada kelompok 2 dijadikan sebagai kelompok kontrol. Intensitas nyeri diukur dengan menggunakan VAS dan hasil yang diperoleh adalah pada awal test mendapatkan nilai 6 dan setelah diberikan perlakuan menjadi 3,80 pada kelompok 1 sedangkan pada kelompok 2 dari nilai 6,20 menjadi $6,10^{19}$. Penelitian lainnya yang dilakukan oleh Murtiningsih,2019 mengenai efek pemberian abdominal stretching pada remaja putri yang mengalami dismenore. Didapatkan hasil dengan pengkuran menggunakan $N R S$ yaitu sebelum perlakuan 6,16 dan setelah perlakuan 3,27. Berdasarkan kedua hasil penelitian diatas, diketahui bahwa metode yang digunakan sama dengan penelitian yang dilakukan di SMA Dwijendra Denpasar, bahwa metode abdominal stretching dapat menurunkan intensitas dismenore primer pada remaja putri. Pemberian abdominal stretching exercise dapat membantu meningkatkan perfusi darah ke uterus dan merileksasikan otot-otot uterus, serta tidak terjadi pembentukan asam laktat, dimana jika terjadi penumpukan asam laktat akan menyebabkan nyeri/kram pada otot. Penumpukan asam laktat tersebut dapat dikurangi dengan proses oksidasi sehingga diperlukan terapi alternatif seperti abdominal stretching untuk melancarkan aliran darah yang membawa oksigen. Dengan begitu terjadilah proses oksidasi yang menurunkan kadar asam laktat dan dapat merelaksasikan otot perut yang kram sehingga nyeri haid dapat berkurang.(Patel,2015)

Selain itu abdominal stretching juga akan merasang proses pengeluaran hormone endorphin yang berperan sebagai penghilang rasa nyeri secara alami di dalam tubuh.

(Ronning,2016)

Sedangkan tambahan kombinasi pada kelompok perlakuan I yaitu teknik core strengthening merupakan latihan penguatan otot core yang salah satu fungsinya adalah untuk memberikan kontrol otot diarea lumbal spine yang baik dan meningkatkan stabilitas fungsional dari trunk (Bill, 2010). Pada penelitian sebelumnya yang dilakukan oleh Berde,2019 mengenai efek dari core strengthening exercise dan chair aerobic exercise pada dismenore primer, 
menggunakan 50 sampel yang dibagi secara acak menjadi 2 kelompok. Hasil yang didapatkan adalah penerapan core strengthening exercise lebih efisien dibandingkan dengan chair aerobic exercise. Sejalan dengan temuan tersebut, penelitian yang dilakukan oleh Shahjerdi,2019 mengenai pemberian core strengthening exercise pada dismenore primer dengan menggunakan jumlah sampel 34 orang (bukan atlet) usia 18-25 tahun dibagi menjadi 2 kelompok perlakuan. Didapatkan hasil bahwa nilai nyeri diukur dengan numeric pain scale dari nilai awal 78,54 menjadi 51,69. Dari kedua penelitian diatas diketahui bahwa metode core strengthening exercise dapat menurunkan nyeri pada dismenore primer. Saat menstruasi core muscle yang lemah akan berakibat terhadap ketidakmampuan tubuh untuk kuat dalam melakukan gerakan fungsional, sehingga akan menurunkan daya tahan tubuh terhadap rasa sakit atau nyeri yang terjadi saat menstruasi. (Bill,2010)

Pemberian core strengthening dapat meningkatkan kekuatan otot-otot core dan meningkatkan stabilitas pada trunk, ketika otot-otot core kuat maka seseorang akan jauh lebi siap untuk menangani tekanan sehari-hari dengan biomekanika yang normal, bahkan ketika tubuh berada dalam tekanan siklus mentruasi. Latihan akan meningkatkan sirkulasi darah ke pelvic. Kapiler-kapiler darah di otot akan mengalami vasodilatasi dan terjadi peningkatan permeabilitas sehingga dapat menstimulasi endorphin yang berperan sebagai analgesic non spesifik, kemudian menurunkan rasa nyeri akibat dismenore (Abbaspour, 2007).

Pada kelompok II diberikan tambahan kombinasi latihan yaitu metode pilates exercise. Metode ini berfungsi untuk meningkatkan fleksibilitas, kekuatan dan daya tahan otot trunk, melatih pernapasan dan meningkatkan koordinasi serta keseimbangan. Berdasarkan penelitian yang dilakukan oleh Paithankar,2016 mengenai perbandingan efektivitas pilates exercise dengan penanganan fiisoterapi konvensional (cat exercise, camel exercise, single leg bridging exercise) pada kasus dismenore primer pada anak remaja. Didapatkan hasil bahwa pilates exercise lebih efektif menurunkan dismenore primer dengan hasil dari 7,4 menjadi 5,8 menggunakan alat ukur VAS. Selain itu temuan lain pada penelitianyang dilakukan oleh mengenai efek dari pilates exercise dan penambahan suplemen pada perubahan prostaglandin dan persepsi dismenore terhadap remaja non atlet. Jumlah sampel 44 orang yang dibagi menjadi 4 kelompok. Kelompok 1 pilates dengan suplemen, kelompok 2 suplemen, kelompok 3 pilates dan kelompok 4 sebagai kelompok kontrol yang dilakukan selama 8 minggu. Didapatkan hasil ketiga kelompok mengalami penurunan sedangkan kelompok 4 tidak mengalami penurunan(Zeinab,2017).

Sejalan dengan temuan diatas pada penelitian di SMA Dwijendra Denpasar juga menggunakan metode pilates exercise mendapatkan penurunan intensitas nyeri dismenore primer. Hal tersebut terjadi karena pada latihan pilates exercise akan memberikan efek penguatan otot-otot punggung bagian bawah,panggul dan otototot inti (core muscle). Pada saat otot berkontraksi terjadi perubahan ukuran otot disertai perbaikan pada muscle pump sehingga sirkulasi darah meningkat dan disertai penurunan hipersensitivitas saraf perifer sehingga rasa menimbulkan penurunan rasa nyeri. Selain itu juga terjadi peningkatan daya tahan otot, fleksibilitas, daya tahan kardiorespirasi, dan menjaga kestabilan hormon pada wanita. Pemberian latihan pilates exercise dapat menjaga metabolisme dan fungsi fisiologi tubuh yang nantinya akan memberikan efek yang baik terhadap sirkulasi darah sehingga mencegah 
terganggunya

oksigen.(Chan,2011)

proses

suplai

B. Kombinasi abdominal stretching dan core strengthening exercise dengan kombinasi abdominal stretching dan pilates exercises efektif dalam menurunkan intensitas dismenore primer

Berdasarkan uji statistik menunjukkan tidak adanya pebedaan antara kelompok perlakuan I dan kelompok perlakuan II. Hal ini terjadi disebabkan oleh beberapa faktor diantaranya: Kurangnya penambahan beban latihan secara bertahap selama pemberian perlakuan. Menurut Bompa tahun 2000 bahwa latihan penguatan otot harus diberikan dengan peningkatan beban secara bertahap yang didasarkan pada frekuensi mingguan. Latihan penguatan otot dipertimbangkan berdasarkan tujuan latihan, berat beban, repetisi, set dan masa istirahat antar set, sedangkan pada penelitian ini frekuensi, set dan interval latihan yang diberikan menetap dari awal hingga akhir perlakuan.

Pada perlakuan I kombinasi abdominal stretching dan core strengthening exercise terjadi sistem anaerobik dikarenakan jumlah gerakan, beban latihan dan waktu latihan pada abdominal stretching hanya terdiri dari 6 gerakan yang diselesaikan dengan perkiraan waktu 5 menit 45 detik yang sudah termasuk istirahat 10 detik diantara setiap set. Kemudian dilanjutkan gerakan core strengthening exercise menggunakan berat badan sebagai beban latihan, terdiri dari 5 gerakan yang dilakukan dengan perkiraan durasi waktu latihan selama 4 menit yang sudah termasuk istirahat 15 detik diantara setiap set. Jadi total latihan pada perlakuan I hanya menghabiskan waktu kurang lebih 9 menit 45 detik. Berdasarkan jenis kontraksi otot pada core strengthening exercise adalah kontraksi isometrik karena pada ke-5 gerakannya tidak ada penambahan panjang otot pada area otot yang dituju (core muscle). Pada latihan anaerobik beban latihan tinggi dengan repetisi minimal atau pengulangan jumlah gerakan yang sedikit. Meningkatkan kekuatan dan daya tahan statis otot ialah keadaan anaerobik dalam otot yang disebabkan oleh karena adanya ischaemia. Keadaan ini terjadi pada waktu dan selama otot berkontraksi. Pada waktu dan selama otot berkontraksi, peredaran darah dalam otot terhenti oleh karena pembuluh-pembuluh darah di dalam otot terjepit selama terjadinya kontraksi itu. Keadaan demikian dijumpai pada kontraksi isometrik.(Giriwijoyo,2007)

Pada perlakuan II kombinasi abdominal stretching dan pilates exercise terjadi perubahan dari sistem anaerobic menjadi sistem aerobik dikarenakan jumlah gerakan, beban latihan dan waktu latihan. Pada abdominal stretching hanya terdiri dari 6 gerakan yang diselesaikan dengan perkiraan waktu 5 menit 45 detik yang sudah termasuk istirahat 10 detik diantara setiap set. Kemudian dilanjutkan gerakan pilates exercise menggunakan berat badan sebagai beban latihan, jumlah gerakan terdiri dari 16 gerakan yang dilakukan sebanyak 2 set. Jadi total latihan pada perlakuan I hanya menghabiskan waktu kurang lebih 23 menit 38 detik. Kontraksi isotonik menunjukkan terjadinya peningkatan tonus disertai dengan pergerakan sendi sehingga terjadi perubahan panjang otot (Arrody,2015). Rangsangan akan meningkatkan daya tahan dinamis pada otot sehingga mengakibatkan keadaan aerobik dalam otot. Keadaan aerobik ini terjadi karena adanya hyperaemia dalam otot. Otot akan mendapat banyak darah bila mekanisme pompa otot (pompa vena) menjadi aktif. Hal ini terjadi bila otot berkontraksi secara singkat tetapi berulangulang, yaitu bila otot melakukan kontraksi isotonik secara cepat dan berulang-ulang. Oleh karena kontraksi isotoniknya berlangsung cepat, sehingga keadaan anaerobiknyapun hanya terjadi sebentar 
pada setiap kali terjadi kontraksi. Hal ini terjadi terutama bila kontraksi isotonik berulang dan tidak menggunakan beban luar. (Giriwijoyo 2009).

\section{SIMPULAN}

1. Kombinasi metode abdominal stretching dengan core strengthening exercise dapat menurunkan intensitas dismenore primer.

2. Kombinasi metode abdominal stretching dengan pilates excercise dapat menurunkan intensitas dismenore primer

3. Tidak ada perbedaan efektivitas kombinasi metode abdominal stretching dengan core strengthening dan abdominal stretching dengan pilates exercises dalam menurunkan intensitas dismenore primer

\section{SARAN}

1. Perlakuan abdominal stretching dengan core strengthening dan abdominal stretching dengan pilates exercise sebaiknya diteruskan dan diterapkan dirumah dengan tujuan menurunkan nyeri haid pada bulan selanjutnya.

2. Untuk peneliti selanjutnya agar menambahkan alat ukur kekuatan otot untuk mengetahui perubahan kekuatan otot yang terjadi.

3. Penambahan beban latihan secara bertahap untuk memaksimalkan peningkatan kekuatan otot.

\section{DAFTAR PUSTAKA}

1. Anurogo, dr. D \& Wulandari, A. 2011. Cara Jitu Mengatasi Nyeri Haid. Yogyakarta : ANDI Proverawati, A., \& Misaroh, S. 2009. Menarche, Menstruasi Pertama Penuh Makna. Yogyakarta: Nuha Medika.

2. Abbaspour, Z., Rostami, A., Najjar, S. 2006. The Effect of Exercise On Primary
Dysmenorrhea. Journal of Resarch in Health Science

3. Arrody, R., Ruliando, H.P., Rina, A.D. 2015. Perbandingan Latihan Otot Isotonik dan Isometrik Terhadap Peningkatan Kekuatan Otot Fleksor Elbow Pada Mahasiswa Program Study Ilmu Keolahragaan Angkatan 2015 Universitas Negeri Jakarta. Hal 18-21. Available at http://journal.unj.ac.id/unj/index. Php/segar/article/download/4577/3433/

4. Badziad, A. 2003. Endokrinologidan Ginekologi. Edisi 2. Media Aesculapius. Jakarta.

5. Bill S, Halvorson R. (2010) Core strengthening For Enhanced Daily Function. Idea Fitness Journal. 7. 25-58

6. Berde.S.D., Trupti. S .Y., Pranjali. M, Sayali. S. G. 2019. Effect of Core Strengthening Exercises \& Chair Aerobic Exercises in Primary Dysmenorrhoea. International Journal of Health Sciences \& Research (www.ijhsr.org) 77 Vol.9; Issue: 3; March 2019.

7. Brown, J and Brown, S. 2010. Exercise for dysmenorrhea. In : Brown J (ed) Cochrane Database of Systematics Review. Chichester, UK : John Wiley \& Sons, Ltd, p.

8. Bustan, M.N., Seweng, A., Ernawati. 2018. Abdominal Stretching Exercise in Decreasing Pain of Dysmenorrhea Among Nursing Students. Journal of Physics: Conference Series 1028 (2018) 012103 Hal. 1-6

9. Chan ,C.W., Mok,N,W., and Yeung,E.W.2011.Aerobic Exercise Trainingin Addition to Conventional Physiotherapy for Cronic Low Back Pain: A Randomized Controlled Trial. Archives of Physical Medicine and Rehabilitation,92(10),1681-1685. 
10. Fortier, M.A., Khrisnaswami, K., Danyod, G., Boucher, S., and Chapdelaine, P. 2008. A Postogonomic Integrated view of Prostaglandins in Reproduction : Implication for Other Body System. Journal Physiology and Pharmacology , 59 (1) : Pages : 65-89

11. Gamit, K,S., Sheth, M,S.,Vyas, N.J.2014. The Effect Of Stretching Exercise On Primary Dysmenorrhea In Adult Girls. International Journal of Medical Science and Public Health | 2014 | Vol 3 | Issue 5 (Online First)

12. Giriwijoyo, H.Y.S.S. 2007. Ilmu Faal Olahraga, Fungsi Tubuh Manusia pada Olahraga, Ed.7., hal 173-187, FPOKUPI.

13. Kisner, C., Colby, L. A. 2012. Therapeutic Exercise Foundation and Technique. Sixth Edition, F. A. Davis Company, Philadelphia.

14. Murtiningsih, S.L., Yuniarti, S. 2019. The Effect Of Abdominal Stretching Exercise On Dysmenorrhea In Adolescent Girls. Journal of Maternity Care and Reproductive Health Volume 2 Issue 3, Hal : 247 - 256

15. Nurwana, Sabilu, Y., Fachlevy, A.F. 2017. Analisis Faktor yang Berhubungan dengan Kejadian Dismenorea pada Remaja Putri di SMA Negeri 8 Kendari Tahun 2016.Jimkesmas.2(6).1-14.

16. Patel, N.S., Tanna, T., and Bhatt, S. 2015. Effect of active stretching exercise on primary dysmenorrhea in college going female students. Indian Journal Physiotherapy Occupation Therapy Volume 9, Hal : $72-76$

17. Paithankar, S.M., Hande, D. 2016. Effectiveness of Pilates over Conventional Physiotherapeutic Treatment in Females with Primary Dysmenorrhea.

18. Proverawati, A., \& Misaroh, S. 2009. Menarche, Menstruasi Pertama Penuh Makna. Yogyakarta: Nuha Medika
19. Ronning A.L. 2016. Get Rid of Menstrual Cramps. Available at: http://www.getridofthings.com/health/w omens-health/get-rid-ofmenstrualcramps/. Accessed on 10 March 2016.

20. Sari, I.E.P., Rumini., Mukkaromah, S.B. 2017. Pengaruh Latihan Senam dan Daya Tahan Tubuh terhadap Respon Nyeri Haid (Dysmenorrhea). Journal of Physical Education and Sports.hal. 165 171.

21. Shah, S., Verma, N., Begani, P., Nagar, H., Mujawar, N. 2016. Effect of exercises on primary dysmenorrhoea in young females. International Journal of Physiotherapy and Research, Int $J$ Physiother Res 2016, Vol 4(5):1658-62. ISSN 2321-1822.

22. Shahjerdi, S., Mahmoudi, F., Sheikhoseini, R., Samira, S. 2019. Effect of Core stability Exercise on Primary Dysmenorrhea : A Randomized Controlled Trial. Journal of Modern Rehabilitation, Volume 13, No : 2, Hal : 113-122.

23. Sundari, L.P.R., Adiputra, N., Adiatmika, I.P.G., Dinata, I.M.K. 2017. Oral Administration of Zinc Capsule for 4 Days before Menstrual Period Decreases Prostaglandin $(P G F 2 \propto)$ Level and Pain Intensity in Women with Primary Dysmenorrhea. International Journal of Science and Research (IJSR), ISSN (Online) : 2319-7064, Volume 6 Issue 3, Hal : 1081-1084

24. Winkjosastro, H. 2009. Ilmu Bedah Kebidanan. Yayasan Bina Pustaka Sarwono Prawirohardjo. Jakarta. FC

25. Zeinab Ali Kiani., Esmaeilzadeh,T,M., Khalatbary.J.A.2017.The Effects Of Pilates Exercise And Caraway Supplementation In The Levels Of Prostaglandin E2 And Perception Dysmenorrhea In Adolescent Grils Non Athelete. Asian Exercise And Sport Science Journal Vol.1 No1 